\title{
The Effects of Institutionalization and Age on Reaction to Frustration of Physically Disadvantaged Children
}

\author{
Samarjeet Kaur and Anju Gautam* \\ Department of Psychology, C.C.S. University, India
}

Submission: May 05, 2017; Published: May 30, 20177

*Corresponding author: Anju Gautam, Department of Psychology, C.C.S. University, Meerut, India, Email: shree772009@gmail.com

\begin{abstract}
The purpose of this current study was to find out the effects of Institutionalization and Age on reaction to frustration of physically disadvantaged children. A sample 240 hearing disadvantaged children from various deaf and dumb schools of Meerut and nearby region adolescents (age group 7-11 years and 11-15 years) was used in this study, Rosenzweig Picture Frustration study (adopted by Udai Pareek) was used. A 2x2 Factorial design was used with first factor institutionalization varied at two levels, i.e. Institutionalization and non institutionalization and the second factor, age also at two levels i.e. 7-11 years old subjects and 11-15 years old subjects. The results depicts higher reaction to frustration and dissection of aggression respectively in obstacle dominance and Impunitiveness in institutionalized subjects than non- institutionalized subjects and the subjects of 11-15 years scored higher on obstacle dominance and impunitiveness than 7-11 years of old age subjects, no interaction effect was observed. 2.
\end{abstract}

Keywords: Institutionalization; Physically disadvantaged children; Reaction to Frustration

\section{Introduction}

OFrustrating situations come about everyday everywhere throughout the life, in school, employment, friendships, marriage and even in relationship with others frustration is a usual component of life, nonetheless, it must not be allowed to achieve the upper hand. Frustration is the significant phenomenon because of its close relation with the understanding with the normal and abnormal behaviour; therefore, it is necessary to understand the nature of frustration and how to cope with it. Collepan [1], Frustration is the result of the thwarting of a native, the organism`s inability temporarily or permanently to proceed toward a desired goal.

Sanforel has defined frustration is an emotional state resulting from being blocked, thwarted or defeated. Houston [2] considered frustration as an unpleasant feeling that results when motive satisfactions is blocked or delayed. Rosenzweig in his interpretation of frustration suggested three types of frustrating situations and reaction towards them - 1. ObstacleDominance -in which the barrier occasioning the frustration stands out in the response. 2. Ego Defence - in which ego of the subjects predominates in the reaction, to frustration. 3. Need-
Persistence -is that type of reaction of frustration in which the solution of the frustrating problem is emphasized Rosenzweig

described three types of direction of aggression: 1. Outward aggression is termed as extrapemitive, 2. Aggression against self was termed as Intropunitive, and besides this he gave a third type of aggression termed as impunitive which results when the individual experiences humiliation and guilt. Among various sources of frustration, the physically disadvantaged is one of the major sources of frustration. A physically disadvantaged child is one who finds himself in unfavourable circumstances because of his physical disability another major source of frustration.

\section{Sources of Frustration}

Physical Environment: The blocks lie in restrictions imposed by external environment physical environment may frustrate us dramatically, through rainfall, earthquakes, famines, floods and others, it also provide innumerable petty hindrance the traffic jam, the uneven road, loud noises and so on. [3] called it "external- privation."

The Social Environment: The social milieu is the significant sources of frustration society sets up norms and rules, tacit 
conventions and prejudices that prevent the satisfaction of the individual needs.

Biological limitations: These obstructions lie in the biological limitations of the individual himself in his motors and mental incapacities.

Psychological complexity: The nature of the situation is such that the satisfaction one need or demand may mean disruption of others.

\section{Objectives}

The Present study was designed to attain the objectives:

A. To study the effects of institutionalization on the reaction to frustration and direction of aggression of physically disadvantaged children.

B. To study the effects of Age on the reaction to Frustration and direction of aggression of physically disadvantaged children [4,5].

\section{Hypothesis:}

a. There is no significant difference in the direction and pattern of frustration of institutionalized and non institutionalized children.

b. There is no significant difference in the direction \& pattern of 7-11 years old age subjects and 11-15 years old age subjects.

c. These exists no significant interaction between institutionalization and age with respect to their effects on direction and pattern of frustration.

\section{Method}

The sample of the present study was drawn from deaf \& dumb schools of Meerut and nearby areas, in which schools of Meerut was Mook Badhir, Vani school and Disha institute and schools of Delhi were government lady Noyci secondary school for deaf, government N.P. school for deaf. The sample included 240 hundred children of students, 120 Institutionlized and 120 non institutionalized children of 7-11 year old age group and 1115 year age group.
Tools

The Indian adaptation of Rosenzweig Picture Frustration study by Udai Pareek [3] was used in this study scale. These are 24 items or cartoon like drawing representing frustrating situations. The scale was constructed to measure the reaction to frustration of the children. The reliability and validity of this scale/test were also determined. The scores reliability as found by comprising the scoring by two independent scores was quite high, the present age of agreement being 79, which increased to 98 after mutual discussion. Reliability co- efficient both for matrix reliability and it were quite high stability ranged from 0.51 to 0.78 and consistency value from 56-99.

\section{Analysis of the Results}

To ascertain the effect of the independent variables on the dependent variable, ANOVA for various reactions to frustration and direction of aggression was used. Results are shown in separate tables for separate measures.

Reaction to frustration: The result of separate reaction to frustration are given below (Table 1):\

Table 1: Obstacle Dominance.

\begin{tabular}{|c|c|c|c|c|c|}
\hline Source of variance & SS & df & $\begin{array}{c}\text { Mean } \\
\text { Varience }\end{array}$ & f & P \\
\hline Institutionalization(A) & 331.40 & 1 & 331.40 & 15.63 & $\mathrm{P}>.001$ \\
\hline Age(B) & 416.13 & 1 & 416.13 & 19.63 & $\mathrm{P}>.001$ \\
\hline $\begin{array}{c}\text { Institutionalization } \\
\text { and Age (AXB) }\end{array}$ & 61.97 & 1 & 61.97 & 2.92 & $\mathrm{NS}$ \\
\hline Within Group & 5001.54 & 236 & 21.19 & & \\
\hline
\end{tabular}

Summary of analysis of analysis of variance of reaction to frustration obstacle dominance reveals significant main effects of institution, f $(1,236=15.63,(\mathrm{P}>.001)$ i.e. institutionalised subjects scored higher $(M=15.90)$ On obstacle dominance than non- institutionalised subjects $(M=13.55)$ and the main effect of age is also significant with $\mathrm{f}(1,236) 19.63(\mathrm{P}>.001)$. The finding reveal that 11-15 years old age group scored higher on obstacle dominance than 7-11 years old age group. The interaction effect of institutionalization and age is non- significant (Table 2).

Table 2: Ego - Defence.

\begin{tabular}{|c|c|c|c|c|}
\hline Source of Variation & SS & df & Mean Variance & f \\
\hline Institutionalization(A) & 10.16 & 1 & 10.16 & 0.11 \\
\hline Age(B) & 269.00 & 1 & .64 & NS \\
\hline $\begin{array}{c}\text { Institutionalization and } \\
\text { age (AXB) }\end{array}$ & .64 & 236.00 & NS \\
\hline Within group & 20401.47 & 86.44 & 0.007 \\
\hline
\end{tabular}


The table revealed the main effects of institutionalization and age are non significant and interaction effects of institutionalization and age is also non - significant (Table 3).

Table 3: Need Persistence.

\begin{tabular}{|c|c|c|c|c|c|}
\hline Source of Variation & SS & $\mathbf{d f}$ & $\begin{array}{c}\text { Mean } \\
\text { Variance }\end{array}$ & $\mathbf{f}$ & $\mathbf{p}$ \\
\hline Institutionalization(A) & 209.46 & 1 & 209.46 & 3.22 & NS \\
\hline Age(B) & 45.10 & 1 & 45.10 & 0.69 & NS \\
\hline $\begin{array}{c}\text { Institutionalization and } \\
\text { Age(AXB) }\end{array}$ & 0.41 & 1 & 0.41 & 0.006 & NS \\
\hline Within Group & 15321.60 & 236 & 64.92 & & \\
\hline
\end{tabular}

The table also revealed that the main effects of institutionalization and age are non-significant and interaction effects of institutionalization and age is also non-significant.

Direction of Aggression: The results of three direction of aggression,i.e. Extrapunitiveness, Intrapunitiveness and Impunitineness are below (Table 4).

Table 4: Extrapunitiveness.

\begin{tabular}{|c|c|c|c|c|c|}
\hline Source of Variation & SS & df & $\begin{array}{c}\text { Mean } \\
\text { Variance }\end{array}$ & $\mathbf{f}$ & $\mathbf{p}$ \\
\hline Institutionalization(A) & 86.40 & 1 & 86.40 & 0.37 & NS \\
\hline Age(B) & 312.80 & 1 & 312.80 & 1.35 & NS \\
\hline $\begin{array}{c}\text { Institutionalization and } \\
\text { Age(AXB) }\end{array}$ & 56.08 & 1 & 56.08 & 0.24 & NS \\
\hline Within Group & 54555.47 & 236 & 231.16 & & \\
\hline
\end{tabular}

It can be seen in the above table that there is non-significant main effect of institutionalization and age. The interaction effect between institutionalization and age. The interaction effect of institutionalization and age is also non-significant (Table 5).

Table 5: Intropunitveness.

\begin{tabular}{|c|c|c|c|c|c|}
\hline Source of Variation & SS & df & $\begin{array}{c}\text { Mean } \\
\text { Variance }\end{array}$ & $\mathbf{f}$ & $\mathbf{p}$ \\
\hline Institutionalization(A) & 53.21 & 1 & 53.21 & 1.89 & NS \\
\hline Age(B) & 5.11 & 1 & 5.11 & 0.18 & NS \\
\hline $\begin{array}{c}\text { Institutionalization and } \\
\text { Age(AXB) }\end{array}$ & 33.00 & 1 & 33.00 & 1.17 & NS \\
\hline Within Group & 6618.69 & 236 & 28.04 & & \\
\hline
\end{tabular}

The table revealed that the main effects of institutionalization and age are non-significant. The interaction effect of institutionalization and age is also non-significant (Table 6).

Table 6: Impunitiveness.

\begin{tabular}{|c|c|c|c|c|c|}
\hline Source of Variation & SS & df & $\begin{array}{c}\text { Mean } \\
\text { Variance }\end{array}$ & $\mathbf{f}$ & $\mathbf{p}$ \\
\hline Institutionalization(A) & 789.00 & 1 & 709.00 & 4.93 & $\mathrm{p}>.05$ \\
\hline Age(B) & 692.00 & 1 & 692.00 & 4.32 & $\mathrm{p}>.05$. \\
\hline $\begin{array}{c}\text { Institutionalization } \\
\text { and Age(AXB) }\end{array}$ & 25.00 & 1 & 25.00 & 0.15 & NS \\
\hline Within Group & 37721.00 & 236 & 159.83 & & \\
\hline
\end{tabular}

It is observed that main effect of institute oratination was significant $\mathrm{f}(1,236)=4.93(\mathrm{P}>.05)$, The institutionalized subjects scored higher $(\mathrm{M}=46.12)$ on impunitiveness than their counter parts $(M=46.55)$ and the main effect of age is also significant with $f(1,236)=4.32(p>.05)$, The findings reveal that the age group of 11-15 years subjects scored higher on impunitiveness than their counterparts, The interaction effect of institutionalization and age is non-significant.

\section{Discussion}

The Present study was conducted to find out the reaction to frustration and direction of aggression among hearing disadvantaged children. Some hypotheses were tested and following results were obtained. In this present study the first hypothesis were these is no significant difference in the direction and pattern of frustration in institutionalization and non-institutionalized children. This hypothesis is rejected in the case of reaction to frustration obstacle dominance. Obstacle dominance means in which barrier occasioning the frustration stands out the response. The result indicates that institutionalized subjects have more obstacle dominance behaviour. In other words for institutionalized subjects irrespective. It may be because the children in institution live in a restrictive environment and are not free to act, they perceive the obstacle as their major source of frustration. This may due to immediate internal and external behaviour such as and other reason is that institutionalized subject's responses are inadequate for dealing with the frustrating situation. The findings of the research is in conformity with the researchers of Sharma and Sharma [6], they also found difference in frustration. But in the second reactions to frustration Ego Defence and Need persistence, there is no significance difference in the institutionalized and noninstitutionalized subjects. So on the reactions to frustration ego defence and need persistence, the first hypothesis that there exists no significant difference in the institutionalized and noninstitutionalized subjects is accepted.

The result pertaining the direction of aggression reveal that the first direction of aggression extrapemitiveness in which aggression of the subject turned on the environment and second direction of aggression of the subject turned on the environment and second direction of aggression intropunitiveness in which aggression is turned by the subject upon himself, results show is no significant difference in the institutionalized and noninstitutionalized subjects $[7,8]$. The null hypothesis is accepted but on the third direction of aggression impunitiveness which means in which aggression is evaded in an attempt to gloss oner the frustration. These the first hypothesis is rejected, because results of this direction of aggression indicated that institutionalised subjects scored higher on impunitiveness than non-institutionalized subjects. Means institutionalized subjects have more impunitive behaviour. This may be due to that children in an institution generally show emotional social and 
academic problems, the earlier the separation from the mother the greater ill effects of that separation.

The second hypothesis was there is no significant difference in the direction and pattern of frustration of 7-11 years old age subjects and 11-15 years old age subjects, this hypothesis is accepted on the reaction to frustration obstacle dominance ego defence and need persistence and direction of aggression extrapunitiveness and intopunitiveness. So here is no significant difference but on the third direction of aggression impunitiveness the results indicate that the age group of 11-15 years subjects scored higher on impunitiveness than 7-11 years subjects. It indicates that all blamer are directed by the subjects of 11-15 years upon themselves or their ego fears loss of love, so they protect itself from alienation by refusing the blame anyone or anything. Thus on this direction of aggression (impunitiveness) null hypothesis is rejected here $[9,10]$.

The third hypothesis of the present study was there exists no significant interaction between institutionalization and age with respect of their effects on the direction and pattern of frustration is accepted on the reactions to frustration obstacle dominance, ego defence and need persistence and direction of aggression extrapunitiveness, intro punitiveness and impunitiveness, because the results indicates that these is no significant effects of interaction of institutionalization and age. Thus it may be interpreted that institutionalization and age did not influence significantly on the direction and pattern of frustration.

\section{Conclusion}

The present study was designed to determine the effects of institutionalization and age on reaction to frustration and direction of aggression of physically disadvantaged children. After the analysis and interpretation of data, the following conclusions have been laid down: i. Significant difference was found in the direction and pattern of Frustration of institutionalized and noninstitutionalized children respectively only on obstacle dominance and impunitiveness.

ii. Significant difference was found in the direction and pattern of frustration of 7-11 years age subjects and 11-15 years age subjects only on obstacle dominance reaction to frustration and impunitiveness direction of aggression.

iii. There is no significant interactional effect of institutionalization and age in the direction and pattern of frustration.

\section{References}

1. Coleman JC (1961) Personality Dynamics and Effective Behaviour. Dell Publishing Co., New York, USA.

2. Houston JP (1979) The Physically Handicapped. Retarded Individuals 15: 43-48.

3. Pareek U, Rosenweig S (1959) Rosenweig's PF Study (children form). Indian Adaptation, Multilingual Edition., Manasayan, Delhi, India.

4. Agarwal S, Sharma S (1998) Extent and Nature of Behaviour among Deaf \& Dumb Children. Indian Educational Abstracts, $\left(7^{\text {th }} \& 8^{\text {th }}\right.$ Edn.), NCERT, New Delhi, India.

5. Anita Sinha (1994) Institutional Development in meerut, A Study of Extent of Mionority Participation. A Thesis, C.C.C. University, Meerut, India.

6. Sharma, Sharma (1977) Motivational and Defective Development. Journal of Psychology and Education 37: 5-6.

7. Krutch D, Crutchfield S (1965) Elements of Psychology: Alfreud A K nopt, New York, USA.

8. Lata Rani (1997) Aggresssive Reaction to Frustration in Physically Handicapped. Journal of Psychological Researches 41(1-2): 42-45.

9. Murphy G (1964) Explorations in personality. Oxford, New York, USA.

10. Robinson SM (1961) Juvenile Delquency: It`s Nature and control. Hol Rinchartand Winston, New Work, USA.

This work is licensed under Creative Commons Attribution 4.0 License

DOI:10.19080/PBSIJ.2017.04.555630

\section{Your next submission with Juniper Publishers} will reach you the below assets

- Quality Editorial service

- Swift Peer Review

- Reprints availability

- E-prints Service

- Manuscript Podcast for convenient understanding

- Global attainment for your research

- Manuscript accessibility in different formats

( Pdf, E-pub, Full Text, Audio)

- Unceasing customer service

Track the below URL for one-step submission https://juniperpublishers.com/online-submission.php 